\title{
Effect of nitrogen fertilization on structure and tillering dynamics of Piata palisade grass during the deferment period
}

\section{Efeito da adubação nitrogenada na estrutura e dinâmica de perfilhamento do capim-piatã durante o período de diferimento}

\author{
Braulio Maia de Lana Sousa ${ }^{1}$; Manoel Eduardo Rozalino Santos ${ }^{2 *}$; Philipe Lima \\ de Amorim ${ }^{3}$; Márcia Cristina Teixeira da Silveira ${ }^{4}$; Gabriel de Oliveira Rocha ${ }^{5}$; \\ Angélica Nunes de Carvalho ${ }^{5}$
}

\begin{abstract}
Nitrogen fertilization can increase the appearance of new tillers, which can improve the structure of deferred sward, since the deferral period is not long. Thus, the objective of this study was to estimate the effects of nitrogen fertilization on structure and tillering dynamics of Piata palisade grass (Brachiaria brizantha cv. Piata) during deferment. We evaluated three nitrogen fertilization levels (none $-0 \mathrm{~kg} \mathrm{ha}^{-1}$; medium - $75 \mathrm{~kg} \mathrm{ha}^{-1}$; and high $\left.-150 \mathrm{~kg} \mathrm{ha}^{-1}\right)$ associated with deferment periods $(1,30,60,90$, and 120 days). The experimental design was set in completely randomised blocks in a split-plot arrangement, with three replications. The deferment period influenced foliage area index quadratically $(p<0.01)$ at all fertilization levels. The improvement in nitrogen fertilization levels increased light interception and reduced the foliage angle, but it did not affect tillering dynamics of Piata palisade grass during the deferment period. Appearance and mortality rates, the balance between tiller appearance and mortality and the stability index of the population of aerial and basal tillers of Piata palisade grass were higher at the beginning of the pasture deferment period. Nitrogen fertilization does not stimulate appearance of tillers on deferred Piata palisade grass. Tiller population stability, however, is only high at the beginning of deferment, decreasing after this initial period.
\end{abstract}

Key words: Brachiaria brizantha. Foliage area index. Stability index. Tiller.

\section{Resumo}

A adubação nitrogenada pode aumentar o aparecimento de novos perfilhos, o que pode melhorar a estrutura do dossel forrageiro diferido, desde que o período de diferimento não seja longo. Dessa forma, objetivou-se estimar os efeitos da adubação nitrogenada na estrutura e dinâmica de perfilhamento do capim-piatã durante o diferimento. Foram avaliadas condições de adubação nitrogenada (ausente - 0 $\mathrm{kg} \mathrm{ha}^{-1}$, média $-75 \mathrm{~kg} \mathrm{ha}^{-1} \mathrm{e}$ alta $\left.-150 \mathrm{~kg} \mathrm{ha}^{-1}\right)$ associadas aos períodos de diferimento $(1,30,60$,

1 Prof., Dr., Universidade Federal de Sergipe, UFS, Departamento de Zootecnia, Programa de Pós-Graduação em Zootecnia, Aracajú, SE, Brasil. E-mail: bmaiasousa@yahoo.com.br

2 Prof., Dr., Universidade Federal de Uberlândia, UFU, Faculdade de Medicina Veterinária, Programa de Pós-Graduação em Ciências Veterinárias, Uberlândia, MG, Brasil. E-mail: manoel.rozalino@ufu.br

3 Prof., Dr., Universidade Federal de Alagoas, UFAL, Centro de Ciências Agrárias, Programa de Pós-Graduação em Zootecnia, Rio Largo, AL, Brasil. E-mail: philipe.amorim@ceca.ufal.br

${ }^{4}$ Dra , Empresa Brasileira de Pesquisa Agropecuária, EMBRAPA Pecuária Sul, Bagé, RS, Brasil. E-mail: marcia.c.silveira@ embrapa.br

5 Zootecnistas, Discentes, Curso de Doutorado do Programa de Pós-Graduação em Ciências Veterinárias, UFU, Uberlândia, MG, Brasil. E-mail: gabriel.o.rocha@hotmail.com.br; angelicanunescoro@hotmail.com

* Author for correspondence 
90 e 120 dias). O delineamento experimental foi o de blocos completos casualizados, em esquema de parcelas subdivididas, com três repetições. $\mathrm{O}$ período de diferimento influenciou o índice de área da folhagem de forma quadrática $(\mathrm{p}<0,01)$ em todas as condições de adubação. A melhoria da condição de adubação nitrogenada aumentou a interceptação de luz e reduziu o ângulo da folhagem, porém não influenciou a dinâmica do perfilhamento durante o período de diferimento do capim-piatã. As taxas de aparecimento e de mortalidade, o balanço entre o aparecimento e mortalidade de perfilhos, e o índice de estabilidade da população de perfilhos aéreos e basais do capim-piatã foram maiores no início do período de diferimento dos pastos. A adubação nitrogenada não estimula o aparecimento de perfilhos do capim-piatã diferido. Já a estabilidade da população de perfilhos é alta apenas no início do período de diferimento, não se mantendo após esse período inicial.

Palavras-chave: Brachiaria brizantha. Perfilho. Índice de área de folhagem. Índice de estabilidade.

\section{Introduction}

Pasture deferment is a grazing management strategy that consists of removing the animals from a given grazing area, usually in the final third of the rainy period, aiming at accumulating forage to be used in grazing conditions during the winter months (SILVA et al., 2016).

During the deferment period, and with the development of the forage plant, the forage mass and foliage area index of the pasture increase (SOUSA et al., 2012). As a consequence, less light reaches the lower part of the sward, which results in lower tiller appearance, as well as mortality of new tillers, which are also smaller (SANTOS et al., 2018). Thus, deferred pasture in general is composed of few heavy tillers with high percentages of stem and dead tissues to the detriment of the live leaf (SANTOS et al., 2010a). These characteristics cause the pasture to have an unfavorable structure for animal intake and performance. To avoid this problem, nitrogen fertilization can be used at the beginning of the deferment period so as to stimulate appearance of new tillers, which have a better morphological composition, and, in fact, better nutritional value (SANTOS et al., 2010b), as long as its use is associated with some adjustment in the plant regrowth. However, because the deferment period takes place in the fall months, when the climate conditions become restrictive to plant growth, the positive effects of nitrogen on pasture tillering may not occur (MORAIS et al., 2006). Moreover, nitrogen might stimulate pasture growth and so the critical foliage area index would be reached earlier, which would also inhibit the appearance of tillers due to the increased shadowing at the base of the pasture.

Therefore, studies on the structure and tillering processes in Piata palisade grass (Brachiaria brizantha $\mathrm{cv}$. Piata) pastures deferred and fertilized are essential for validating the aforementioned hypotheses and to define suitable management practices during the deferment period.

\section{Material and Methods}

This study was conducted in the Forage Sector of the Federal University of Viçosa (UFV), located in Viçosa, MG, Brazil (2045' South latitude and $42^{\circ} 51^{\prime}$ 'West longitude; $651 \mathrm{~m}$ altitude), in the period from 01 March 2011 to 01 July 2011. The climate of the region is a subtropical Cwa, having welldefined dry (in the coldest months) and rainy (in the summer) seasons (KÖPPEN, 1948). During the experimental periods, the climate data were obtained at the meteorological station of UFV, located 1,000 $\mathrm{m}$ away from the experimental area (Table 1). 
Table 1. Monthly means of minimum, average and maximum temperature, precipitation and total monthly evaporation from March to July 2011.

\begin{tabular}{cccccc}
\hline Month & $\begin{array}{c}\text { Average tempera- } \\
\text { ture }\left({ }^{\circ} \mathrm{C}\right)\end{array}$ & $\begin{array}{c}\text { Minimum tem- } \\
\text { perature }\left({ }^{\circ} \mathrm{C}\right)\end{array}$ & $\begin{array}{c}\text { Maximum tem- } \\
\text { perature }\left({ }^{\circ} \mathrm{C}\right)\end{array}$ & $\begin{array}{c}\text { Precipitation } \\
(\mathrm{mm})\end{array}$ & $\begin{array}{c}\text { Evaporation } \\
(\mathrm{mm})\end{array}$ \\
\hline March & 22.1 & 19.1 & 27.5 & 284.4 & 53.4 \\
April & 20.8 & 17.3 & 26.9 & 56.6 & 53.6 \\
May & 17.6 & 13.7 & 24.7 & 2.6 & 57.7 \\
June & 15.9 & 11.5 & 23.1 & 23.0 & 64.4 \\
July & 15.6 & 9.9 & 24.1 & 0.0 & 60.9 \\
\hline
\end{tabular}

We utilized an area of approximately $288 \mathrm{~m}^{2}$, established with Piata palisade grass on a RedYellow Latosol of clayey texture (EMBRAPA, 2006). According to the results of the chemical analysis, performed at the beginning of the experimental period on the $0-20 \mathrm{~cm}$ layer, the soil presented the following characteristics: $\mathrm{pH}$ in $\mathrm{H}_{2} \mathrm{O}$ : 5.50; P (Mehlich-1): $1.40 \mathrm{mg} \mathrm{dm}^{-3}$ and $\mathrm{K}: 36.0040$ $\mathrm{mg} \mathrm{dm}{ }^{-3} ; \mathrm{Ca}^{2+}: 2.10 \mathrm{cmol}_{\mathrm{c}} \mathrm{dm}^{-3} ; \mathrm{Mg}^{2+}: 0.70 \mathrm{cmol}_{\mathrm{c}}$ $\mathrm{dm}^{-3}$ and $\mathrm{Al}^{3+}: 0.00 \mathrm{cmol}_{\mathrm{c}} \mathrm{dm}^{-3}\left(\mathrm{KCl} 1 \mathrm{~mol} \mathrm{~L}^{-1}\right)$. Based on these results, the soil was not limed. At the beginning of the deferment period (01 March 2011) $60 \mathrm{~kg}$ phosphorus ha ${ }^{-1}$ was applied in the form of superphosphate and $60 \mathrm{~kg}$ potassium ha ${ }^{-1}$ in the form of potassium chloride, in a single dose.

The design adopted was set in completely randomized blocks with three replications in an arrangement of repeated measures in time, where we assessed three nitrogen fertilization levels: none $\left(0 \mathrm{~kg} \mathrm{~N}\right.$ ha $\left.{ }^{-1}\right)$, medium (75 $\left.\mathrm{kg} \mathrm{ha}^{-1}\right)$ and high (150 $\left.\mathrm{kg} \mathrm{ha}^{-1}\right)$ and pasture deferment periods $(1,30,60$, 90 and 120 days).

At the beginning of the experimental period (01 March 2011), the Piata palisade grass was lowered to $20 \mathrm{~cm}$ in height (SOUSA et al., 2012; VILELA et al., 2012) by a mechanical cutting. On the same day nitrogen doses were also applied in the form of urea at a single dose, in the late afternoon. After fertilization and only on the first day of the experimental period the area was manually irrigated with a plastic hose so as to elevate soil moisture and increase efficiency in the use of fertilizers.
Our objective was to simulate a water input to the soil corresponding to a precipitation of $5 \mathrm{~mm}$. This strategy was also employed to simulate what usually happens in practice, i.e., the application of fertilizers on pastures at the beginning of deferment and after the occurrence of rainfall, when the soil still presents a satisfactory moisture content. The Piata palisade grass remained deferred until 01 July 012011.

Light interception by the sward, foliage area index and foliage angle (comprising leaf, stem and dead tissue) were measured with a LAI 2000 canopy analyser (LI-COR ${ }^{\circledR}$ ), at two random points per experimental unit. At each point, one reading was made above the sward and five on the soil surface, making a total of 10 readings at soil surface per experimental unit. Evaluations were carried out at the beginning of the experimental period ( 01 March 2011) and at every 30 days until the end of the deferment period (01 July 2011).

Tiller demographic patterns data were collected from the inside of two PVC rings of $30 \mathrm{~cm}$ in diameter at every experimental unit. They were fixed in the soil with metal clips at locations that represented the average sward height at the beginning of the evaluations. In the first evaluation (01 March 2011), all existing tillers in the area were tagged with threads of the same colour to identify the generation of control tillers. All tagged tillers were recounted every 30 days; new tillers were tagged with a different colour from that utilized at the previous tagging; the threads of dead tillers were 
removed. In each tiller count and tagging procedure, they were distinguished between aerial and basal according to the location of their origin. Aerial tillers corresponded to those originated from a main basal tiller, and therefore did not have their own root system. Basal tillers were those that grew directly in the soil and presented their own root system.

Based on these counts we estimated separately for basal and aerial tillers: appearance [(emerged tillers/ total live tillers at the previous tagging) $\times$ $100]$, mortality [(dead tillers/total live tillers at the previous tagging $) \times 100$ ], survival $(100-$ tiller mortality rate) and flowering [(flowering tillers/total live tillers at the previous tagging) $\times 100$ ] rates, as well as the balance between tiller appearance and mortality (appearance rate - mortality rate) and the tiller population stability index [survival rate $\times(1+$ appearance rate)].

All the dataset was tested to make sure that the basic prerogatives of variance analysis were met. Only tiller mortality and survival rates met the basic assumptions of the variance analysis. Even transformed, the other characteristics did not meet the assumptions and so they were analysed using nonparametric statistics.

Foliage area index, light interception and foliage angle were precisely measured during the deferment period. Thus, for these traits, deferment period was considered a quantitative factor, whose levels were 1, 30, 60, 90 and 120 days. In this case, regression analyses were performed, considering models that best fit the data.
For the descriptive characteristics of tillering dynamics, the values were obtained in periods throughout the pasture deferment. With this, the deferment period was considered a qualitative factor, whose levels were periods of 1 to 30,31 to 60,61 to 90 , and 91 to 120 days. Therefore, the comparison between the means of the levels of this factor, as well as of the factor 'nitrogen fertilization' was performed by the Student-Newman-Keuls test with significance of $5 \%$.

\section{Results and Discussion}

There was interaction between the nitrogen fertilization and the deferment time to foliage area index (Table 2), which was quadratically influenced by the deferment period ( $\mathrm{P}<0.05)$, regardless of the nitrogen level utilized (Table 2). The foliage area index increased along with the advance in the deferment period up to the maximum recorded values of 84,100 and 82 days for the 'none', medium (75 $\mathrm{kg})$ and high $(150 \mathrm{~kg})$ nitrogen fertilization levels, respectively. There was no difference in foliage area index between the nitrogen doses evaluated in the first deferment period. On day 30, the Piata palisade grass deferred with medium and high nitrogen fertilization levels showed a higher foliage area index in relation to that deferred without nitrogen. At 60, 90 and 120 days of deferment, foliage area index increased with the better nitrogen fertilization levels (Table 2).

Table 2. Foliage area index of Piata palisade grass pastures deferred under three nitrogen fertilization levels during the deferment period.

\begin{tabular}{cccccc}
\hline \multirow{2}{*}{ Nitrogen fertilization } & \multicolumn{5}{c}{ Deferment period (day) } \\
\cline { 2 - 6 } & 1 & 30 & 60 & 90 & 120 \\
\hline None $^{1}$ & $1.33 \mathrm{a}$ & $2.76 \mathrm{~b}$ & $3.28 \mathrm{c}$ & $3.58 \mathrm{c}$ & $3.43 \mathrm{c}$ \\
Medium $^{2}$ & $1.49 \mathrm{a}$ & $4.40 \mathrm{a}$ & $4.67 \mathrm{~b}$ & $4.94 \mathrm{~b}$ & $5.10 \mathrm{~b}$ \\
High $^{3}$ & $1.71 \mathrm{a}$ & $4.84 \mathrm{a}$ & $6.03 \mathrm{a}$ & $6.44 \mathrm{a}$ & $5.83 \mathrm{a}$ \\
\hline
\end{tabular}

${ }^{1} 1,3467+0,0501 \mathrm{D}-0,0003 \mathrm{D}^{2}, \mathrm{R}^{2}: 0,99 ;{ }^{2} 1,7198+0,0799 \mathrm{D}-0,004 \mathrm{D}^{2}, \mathrm{R}^{2}: 0,91:{ }^{3} 1,7247+0,1142 \mathrm{D}-0,0007 \mathrm{D}^{2}, \mathrm{R}^{2}: 0,99$. Means followed by the same lowercase letter in the column do not differ according to the SNK test $(\mathrm{P}>0.05)$. 
Neither light interception by the sward nor foliage angle seemed to have been affected $(\mathrm{P}>0.05)$ by interaction between nitrogen fertilization levels and time of deferment. The better nitrogen fertilization levels increased $(\mathrm{P}<0.05)$ light interception by the sward (Figure 1). The Piata palisade grass deferred with medium $\left(43.4^{\circ}\right)$ and high $\left(41.9^{\circ}\right)$ nitrogen fertilization showed a lower $(\mathrm{P}<0.05)$ foliage angle in relation to those deferred without nitrogen $\left(48.6^{\circ}\right)$ (Figure 1).

Figure 1. Light interception and foliage angle of the Piata palisade grass deferred under three nitrogen fertilization levels.

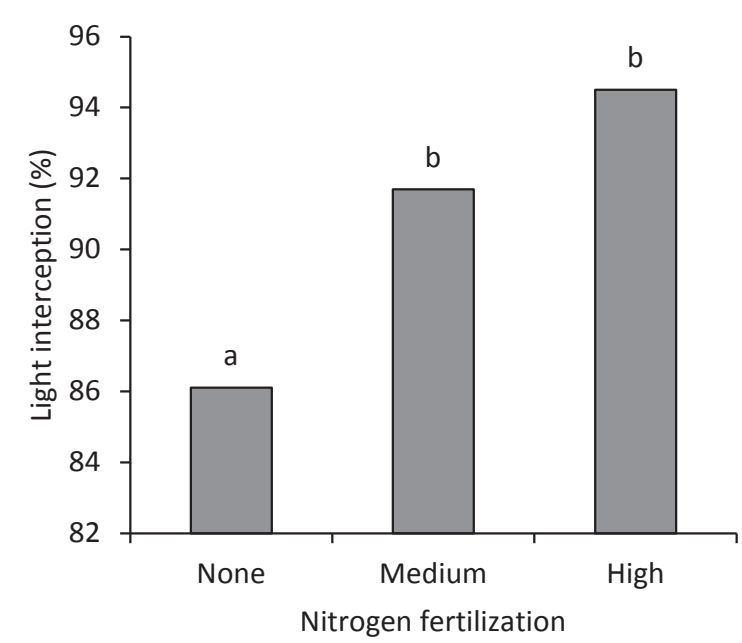

Nitrogen fertilization levels did not affect $(\mathrm{P}>0.05)$ the descriptive characteristics of the tillering dynamics of the deferred Piata palisade grass. However, the appearance rate of basal and aerial tillers was affected $(\mathrm{P}<0.05)$ by the period

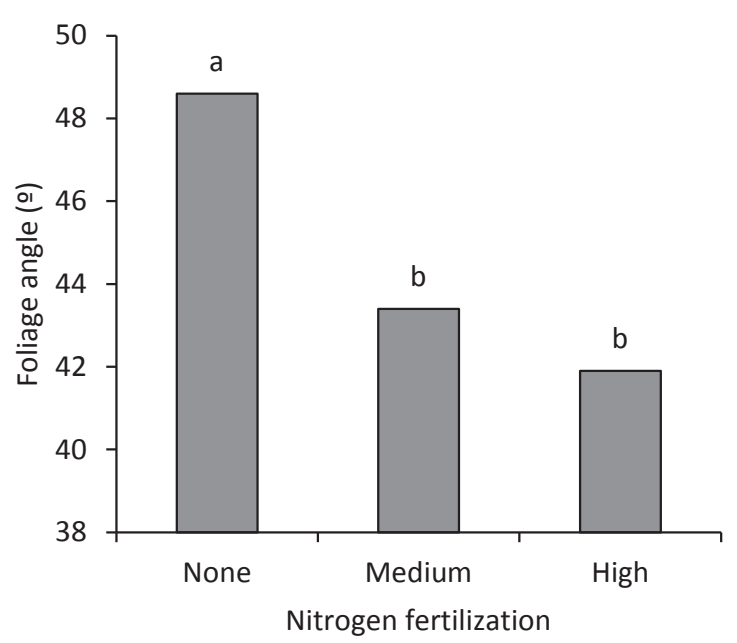

of deferment: the Piata palisade grass deferred between days 1 and 30 showed higher basal and aerial tiller appearance rate in comparison with the other periods assessed (Table 3).

Table 3. Descriptive traits of tiller population dynamics of Piata palisade grass during the deferment period.

\begin{tabular}{|c|c|c|c|c|c|c|}
\hline \multirow{2}{*}{ Characteristic } & \multicolumn{4}{|c|}{ Deferment period (day) } & \multirow{2}{*}{ P-value } & \multirow{2}{*}{$\mathrm{CV}(\%$} \\
\hline & 1 to 30 & 31 to 60 & 61 to 90 & 91 to 120 & & \\
\hline \multicolumn{7}{|c|}{ Basal tiller } \\
\hline TAR & $128.6 \mathrm{a}$ & $4.9 \mathrm{~b}$ & $0.7 \mathrm{~b}$ & $1.6 \mathrm{~b}$ & 0.0289 & 23.62 \\
\hline TMR & $27.1 \mathrm{a}$ & $17.9 \mathrm{ab}$ & $15.4 \mathrm{ab}$ & $11.1 \mathrm{~b}$ & 0.0209 & 19.30 \\
\hline BAL & $101.5 \mathrm{a}$ & $-10.5 b$ & $-17.3 b$ & $-9.6 b$ & 0.0001 & 39.94 \\
\hline TSR & $72.9 \mathrm{~b}$ & $84.6 \mathrm{ab}$ & $82.1 \mathrm{ab}$ & $88.9 \mathrm{a}$ & 0.0006 & 19.30 \\
\hline SI & $1.7 \mathrm{a}$ & $0.9 \mathrm{~b}$ & $0.8 \mathrm{~b}$ & $0.9 \mathrm{~b}$ & 0.0209 & 19.30 \\
\hline TFR & 1.1 & 1.5 & 3.0 & 2.4 & 0.8427 & 78.65 \\
\hline
\end{tabular}




\begin{tabular}{ccccccc}
\hline \multicolumn{7}{c}{ Aerial tiller } \\
TAR & $970.9 \mathrm{a}$ & $14.3 \mathrm{~b}$ & $3.2 \mathrm{~b}$ & $0.5 \mathrm{~b}$ & 0.0002 & 33.67 \\
TMR & $54.9 \mathrm{a}$ & $35.9 \mathrm{ab}$ & $15.0 \mathrm{~b}$ & $24.6 \mathrm{~b}$ & 0.0128 & 25.67 \\
BAL & $916.0 \mathrm{a}$ & $-21.7 \mathrm{~b}$ & $-11.8 \mathrm{~b}$ & $-24.2 \mathrm{~b}$ & 0.0004 & 37.87 \\
TSR & $45.2 \mathrm{~b}$ & $64.0 \mathrm{ab}$ & $85.0 \mathrm{a}$ & $75.4 \mathrm{a}$ & 0.0128 & 25.67 \\
SI & 3.8 & 0.7 & 0.9 & 0.8 & 0.2688 & 31.01 \\
TFR & 2.8 & 0.0 & 1.2 & 0.2 & 0.7825 & 67.12 \\
\hline
\end{tabular}

TAR: tiller appearance rate (tiller 100 tillers $^{-1} 30$ days $^{-1}$ ); TMR: tiller mortality rate (tiller 100 tillers $^{-1} 30$ days $^{-1}$ ); BAL: balance between tiller appearance and mortality (tiller 100 tillers $^{-1} 30$ days ${ }^{-1}$ ); TSR: tiller survival rate (tiller 100 tillers $^{-1} 30$ days $^{-1}$ ); SI: tiller population stability index; TFR: tiller flowering rate (tiller 100 tillers $^{-1} 30$ days $\left.^{-1}\right)$; CV: coefficient of variation. Means in the row followed by different letters differ according to the SNK test $(\mathrm{P}>0.05)$.

The effect of nitrogen on the forage plant is linked to improvement in soil fertility. When absorbed by the plant, this nutrient elevates the number of cells under division and stimulates cell elongation (SCHNYDER et al., 2000), accelerating the plant growth and development rates (MARTUSCELLO et al., 2006) and promoting an expressive increase in forage accumulation (DURU; DUCROCQ, 2000). Higher plant growth and development rates result in formation of longer (SOUSA et al., 2012) and heavier leaf blades, which contribute to their being more horizontally arranged (lower foliage angle).

The fact that the first evaluation of Piata palisade grass (day 1) was performed simultaneously with nitrogen fertilization resulted in absence of difference in the foliage area index between the doses evaluated (Table 2). However, evaluating this period was important to demonstrate that the Piata palisade grass presented the same condition at the beginning of deferment.

The advance in the deferment period increased the foliage area index of Piata palisade grass up to a maximum value specific for each nitrogen fertilization level; from this maximum value, the foliage area index tended to stabilize or decrease (Table 2).

The plant responses to defoliation should be viewed as a mechanism of reestablishment and maintenance of the growth patterns, in which all factors available must be used for the formation of new photosynthesizing tissues (SILVA et al., 2015). At the beginning of regrowth, the intraspecific competition for light is smaller due to the lower leaf area indices (Table 2) and light interception. Such conditions cause the forage accumulation at the beginning of regrowth to be basically composed of leaves, because the leaf appearance and elongation (PEREIRA et al., 2018) as well as tiller appearance rates (DIFANTE et al., 2008) are higher. However, at a more advanced regrowth stage the higher competition for light between the tillers reduces the quantity and quality of light that penetrates the sward, which increases shading at the base of the tiller and consequently accelerates leaf senescence in plants (BIRCHAM; HODGSON, 1983), which explains the stabilization of the foliage area index after the approximate 90 days of deferment (Table 2).

Despite the stabilization of the foliage area index after the 90 days of deferment, the improvement in nitrogen fertilization increased the maximum foliage area index of the deferred Piata palisade grass. This demonstrates the possibility of intensifying forage production with nitrogen fertilization, since there is a close relationship between forage production and the leaf area of a plant (SILVA et al., 2015). However, the higher foliage area index of the Piata palisade grass deferred with a higher nitrogen dose does not necessarily mean elevated leaf accumulation. 
Mortality and survival rates of basal tiller of Piata palisade grass were higher from 1 to 30 days, intermediate from 21 to 60 days and from 61 to 90 days, and lower from 91 to 120 days. The same behaviour pattern was observed for aerial tillers (Table 3).

The balance between appearance and mortality of basal and aerial tillers varied $(\mathrm{P}<0.05)$ during the deferment period, with a higher value recorded in the period from 1 to 30 days in relation to the periods from 31 to 60,61 to 90 , and 91 to 120 days of deferment (Table 3). A similar response pattern was found for the population stability index of basal tillers (Table 3 ). On the other hand, the stability rate of aerial tillers and the flowering rate of basal and aerial tillers were not affected by time of deferment (Table 3).

At the beginning of regrowth, competition for light is reduced and, as a consequence, the quantity and quality of the light that penetrates the inside of the sward is elevated. Coupled with the higher occurrence of rain at the beginning of the deferment period (March) (Table 1), this fact increased the appearance rates of basal and aerial tillers, also elevating the balance between tiller appearance and mortality and higher basal and aerial tiller population stability indices in the period from 1 to 30 days (Table 3 ).

However, there is a dynamic and harmonic mechanism between the processes of tiller appearance and mortality, as a way to keep the tiller population stable in a given environment and management condition (SILVA et al., 2008). As the deferment period advanced, the availability of abiotic factors favourable to plant growth decreased due to the adverse climate conditions (Table 1). In addition, during the deferment period the competition for light increased (Table 2), which reduced tiller appearance rate.

In spite of preventing a more marked reduction of the tiller population, the adjustments made in the appearance, mortality and survival rates were not sufficient to keep the tiller population stable for deferment periods longer than 30 days. This fact can be inferred by the negative balance between tiller appearance and mortality in the deferment periods of 31 to 60 days, 61 to 90 days, and 91 to 120 days (Table 3), which demonstrates that mortality rate was higher than the basal and aerial tiller appearance rates.

Having the population stability index, a joint analysis of the effects of variations in the tiller appearance and mortality rates can be performed. In general, values lower than 1.0 indicate that survival and appearance of new tillers are not enough to offset the mortality rates, and so the population would tend to decrease. Values higher than 1.0 suggest the opposite situation, whereas values close to 1.0 indicate a stable tiller population, in which the number of tillers practically does not vary, although it is the result of a dynamic balance (DUCHINI et al., 2017).

In this regard, except for the period from 1 to 30 days of deferment, the stability index of basal and aerial tillers of Piata palisade grass was lower than 1.0 (Table 3). This demonstrates that in the longer deferment periods the tiller population was reduced. Accordingly, Santos et al. (2010a) verified that a longer deferment period resulted in decreased number of vegetative tillers on Brachiaria decumbens cv. Basilisk pastures. It is possible that vegetative and smaller tillers have been shaded and died due to the competition for light with the older (larger) tillers during the deferment period, besides the restrictive climatic conditions impacting plant growth (Table 1). In a shading situation, a higher amount of assimilates is allocated for the growth of existing tillers to the detriment of new ones (ROBSON et al., 1988).

The negative balance between the rates of appearance and mortality of tillers of Piata palisade grass deferred longer indicates that this management strategy could compromise the persistence of this forage plant. The climate conditions restrictive to 
plant growth at the end of the fall and during the winter (Table 1), when the Piata palisade grass remained deferred, had a prevailing inhibitory effect on tillering, and consequently annulled the possible benefits of reducing the pasture height on its tillering. Nevertheless, during the seasons that are restrictive to the plant growth, it is common to see an increase in the death rate of the tillers (SANTOS et al., 2011; MORAIS et al., 2006). With the return of the rainy season (spring), this density reestablishes itself due to the elevation in the tiller appearance rate, without a decrease in the persistence of the plant community in a certain management.

It is important to emphasize that even though nitrogen fertilization had no effect on the tillering of the deferred Piata palisade grass, there are other benefits associated with nitrogen fertilization on the pasture to be deferred, such as making pasture use flexible during the rainy period and having a younger tiller profile during the utilization of the deferred pasture. Thus, the pasture will have a better morphological composition and nutritional value, thereby presenting a predisposing structure to grazing, allowing for significant gains in terms of animal production during the winter.

\section{Conclusions}

Nitrogen fertilization anticipates the competition for light in the sward during the deferment period and does not stimulate the appearance of tillers on the deferred Piata palisade grass. The stability of the population of Piata palisade grass tillers is only high at the beginning of the deferment period, decreasing after this initial period.

\section{References}

BIRCHAM, J. S.; HODGSON, J. The influence of sward condition on rates of herbage growth and senescence in mixed swards under continuous stocking management. Grass and Forage Science, Oxford, v. 38, n. 4, p. 323$331,1983$.
DIFANTE, G. S.; NASCIMENTO JÚNIOR, D.; SILVA, S. C.; EUCLIDES, V. P. B.; ZANINE, A. M.; ADESE, B. Dinâmica do perfilhamento do capim marandu cultivado em duas alturas e três intervalos de corte. Revista Brasileira de Zootecnia, Viçosa, MG, v. 37, n. 2, p. 189 196, 2008.

DUCHINI, P. G.; GUZATTI, G. C.; RIBEIRO-FILHO, H. M. N.; SBRISSIA, A. F. Changes in tillering dynamics of intercropped black oat and annual ryegrass ensure a stable sward. Experimental Agriculture, Cambridge, v. 1, n. 1, p. 1-12, 2017.

DURU, M.; DUCROCQ, H. Growth and senescence of the successive grass leaves on a tiller. Ontogenic development and effect of temperature. Annals of Botany, Oxford, v. 85, n. 1, p. 635-643, 2000.

EMPRESA BRASILEIRA DE PESQUISA AGROPECUÁRIA - EMBRAPA. Centro Nacional de Pesquisa de Solos. Sistema Brasileiro de classificação de solos. 2. ed. Rio de Janeiro: EMBRAPA Solos, 2006.

KÖPPEN, W. Climatologia: con un estudio de los climas de la tierra. Pánuco: Fondo de Cultura Econômica, 1948. $479 \mathrm{p}$.

MARTUSCELLO, J. A.; FONSECA, D. M.; NASCIMENTO JÚNIOR, D.; SANTOS, P. M.; CUNHA, D. N. F. V.; MOREIRA, L. M. Características morfogênicas e estruturais do capim-massai submetido a adubação nitrogenada e desfolhação. Revista Brasileira de Zootecnia, Viçosa, MG, v. 35, n. 3, p. 665-671, 2006.

MORAIS, R. V.; FONSECA, D. M.; NASCIMENTO JUNIOR, D.; RIBEIRO JÚNIOR, J. I.; FAGUNDES, J. L.; MOREIRA, L. M.; MISTURA, C.; MARTUSCELLO, J. A. Demografia de perfilhos basilares em pastagem de Brachiaria decumbens adubada com nitrogênio. Revista Brasileira de Zootecnia, Viçosa, MG, v. 35, n. 2, p. 380388, 2006.

PEREIRA, L. E. T.; HERLING, V. R.; AVANZI, J. C.; SILVA, S. C. da. Morphogenetic and structural characteristics of signal grass in response to liming and defoliation severity. Pesquisa Agropecuária Tropical, Goiânia, v. 48, n. 1, p. 1-11, 2018.

ROBSON, M. J.; RYLE, G. J. A.; WOLEDGE, J. The grass plant: its form and function. In: JONES, M. B.; LAZENBY, A. (Ed.). The grass crop: the physiological basis of production. London: Chapman and Hall, 1988. p. 25-83.

SANTOS, M. E. R.; ÁVILA, A. B.; CARVALHO, A. N.; ROCHA, G. O.; VAN CLEEF, F. O. S.; SEGATTO, B. N.; VASCONCELOS, K. A.; PEREIRA, R. S. Marandu palisade grass management strategies at the beginning 
of the deferment period and effects on tillering. Semina. Ciências agrárias, Londrina, v. 39, n. 4, p. 1617-1626, 2018.

SANTOS, M. E. R.; FONSECA, D. M.; BALBINO, E. M.; SILVA, S. P.; MONNERAT, J. P. I. S. Valor nutritivo de perfilhos e componentes morfológicos em pastos de capim-braquiária diferido e adubado com nitrogênio. Revista Brasileira de Zootecnia, Viçosa, MG, v. 39, n. 9, p. 1919-1927, 2010b.

SANTOS, M. E. R.; FONSECA, D. M.; GOMES, V. M.; BALBINO, E. M.; MAGALHÃES, M. A. Estrutura do capim-braquiária durante o diferimento da pastagem. Acta Scientiarum. Animal Science, Maringá, v. 32, n. 2, p. 139-145, 2010a.

SANTOS, M. E. R.; FONSECA, D. M.; GOMES, V. M.; NASCIMENTO JUNIOR, D.; GOMIDE, C. A. M.; SBRISSIA, A. F. Capim-braquiária sob lotação contínua e com altura única ou variável durante as estações do ano: Dinâmica do perfilhamento. Revista Brasileira de Zootecnia, Viçosa, MG, v. 40, n. 11, p. 2332-2339, 2011.

SCHNYDER, H.; SCHÄUFELE, R.; VISSER, R.; NELSON, C. J. An integrated view of C and $\mathrm{N}$ uses in leaf growth zones of defoliated grasses. In: LEMAIRE, G.; HODGSON, J.; MORAES, A.; CARVALHO, P. C. F.; NABINGER, C. (Ed.). Grassland ecophysiology and grazing ecology. Wallingford: CAB International, 2000. p. 41-60.

SILVA, C. S.; MONTAGNER, D. B.; EUCLIDES, V. P. B.; QUEIROZ, C. A.; ANDRADE, R. A. S. Steer performance on deferred pastures of Brachiaria brizantha and Brachiaria decumbens. Ciência Rural, Santa Maria, v. 46, n. 11, p. 1998-2004, 2016.

SILVA, S. C. da; NASCIMENTO JÚNIOR, D.; EUCLIDES, V. P. B. Pastagens: conceitos básicos, produção e manejo. Viçosa, MG: Suprema, 2008. 115 p.

SILVA, S. C. da; SBRISSIA, A.; PEREIRA, L. E. T. Ecophysiology of $\mathrm{C} 4$ forage grasses: understanding plant growth for optimising their use and management. Agriculture, Switzerland, v. 5, n. 3, p. 598-625, 2015.

SOUSA, B. M. L.; VILELA, H. H.; SANTOS, A. L.; SANTOS, M. E. R.; NASCIMENTO JÚNIOR, D.; ASSIS, C. Z.; FARIA, B. D.; ROCHA, G. O. Piatã palisade grass deferred in the fall: effects of initial height and nitrogen in the sward structure. Revista Brasileira de Zootecnia, Viçosa, MG, v. 41, n. 5, p. 1134-1139, 2012.

VILELA, H. H.; SOUSA, B. M. L.; SANTOS, M. E. R.; FARIA, B. D.; NASCIMENTO JÚNIOR, D. Forage mass and structure of piatã grass deferred at different heights and variable periods. Revista Brasileira de Zootecnia, Viçosa, MG, v. 41, n. 7, p. 1625-1631, 2012. 
